\title{
INDEX TO VOLUME XIII
}

A

Aboullah (S. M.), Descriptive Catalogue of the Persian, Urdu, and Arabic Manuscripts in the Panjab University Library, Vol. I, fasc. $i i$, 508-9.

'Abdu-' 'L Qūdir 'L-Maghribĩ (Shaykh) ed. Tá 'iyyatu 'āmiri bni 'āmiri 'l-Bașri, 776-7.

Aboriginal Tribes of Hyderabad. Vol. III: The Raj Gonds of Adilabad, a Peasant Culture of the Deccan. Book I: Myth and Ritual, The (C. von Fürer-Haimendorf and E. von Fürer-Haimendorf), 1048-9.

Amraham (R. C.) and Kano (Malam MaI), Dictionary of the Hausa Language, 524-9.

Abü-L-QĀSIM al-Maǵribi, De l'éthique, 778. äce, $932-3$.

Acta Orientalia, Vol. XXI, 1062.

Adam (H. J. F.) and FiRTh (J. R.), Improved Techniques in Palatography and Kymography, 771-4.

Ad BSÖAS., xiii, 1950, p. 275 : $\dot{g} r k h$ frt $=$ Oxford (P. Wittek), 1045.

xxsæveuัat, 136.

AFFIFI (A. E.), The Influence of Hermetic Literature on Moslem Thought, 840-855.

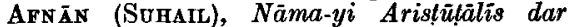
Bāra-yi Hunar-i Shi $r$, 782-3.

AiYangar (A. N. Krishra) and Murti (G. Skinivasa), Edicts of Aśoka, 1066.

Allen (W. S.), Some Prosodic Aspects of Retroflexion and Aspiration in Sanskrit, 939-946 ; rev., 792-5.

Amo Kwan in Burmese, 427-8.

amuka-nàman-, 655.

$A m u$ Kwan, $A m \bar{u}$ Kwan in Burmese, 427.

ANDERSON (J. N. D.), Homicide in Islamic Law : I. The Concept of the Offence : Tort or Crime?, 811-828; Invalid and Void Marriages in Hanafi Law, 357-366.

Anekärtha-Tilaka of Mahipa (ed. Madhukar Mangesh Patkar), 237-8.

*An Luhshan Shyhji, 460-1.

Apocalyptic Vision of Islamic History, An (B. Lewis), 308-338.

A pokapa or Poinai Theōn, 146 ff.

AQuilina (J.), rev., 225-6.

Aquinas (St. Thomas), theology of, 551 f.

Aramaic Inscription of Asoka found in Lampāka, The (W. B. Henning), 80-88.

ARBERRy (A. J.), New Materials on the Tabaqāt al-shu'arä' of al-Jumahì I. 7-22; II, 602-615; The Teachers of Shihāb alDin 'Umar al-Suhrawardī, 339-356 ; rev., 235-6, 782-3.

A rouaia, $149 \mathrm{ff}$

Asia MIajor, Vol. I, part i (ed. B. Schindler), $799-800$.

Assi in Ossetic, 135.

\section{B}

BABUY: (IBN), The Reasons for Laws, $829 \mathrm{ff}$.

BaILeY (D. R. Shackleton), The Varnārhavarna Stotra of Mātriceța I, 671-702; II, 947-1003.

BATEY (H. W.), Irano-Indica II, 121-139; III, 389-409; IV, 920-938 ; The Tumshuq Karmavācanā, 649-670.
BaILey (H. W.) and Henderson (E. J. A.), Digoron Word-List, 381-8.

Balinu $u$ s the Philosopher, the book of, 847-9.

BaLJON, Jr. (J. M. S.), The Reforms anl Religious Ideas of Sir Sayyid Ahmad Khān, 1065-6.

BarnetT (K. M. A.), A Transcription of Cantonese, 725-745.

BarnetT (L. D.), rev., 240-4.

Basham (A. L.), Recent Work on the Indus Civilization, $140-5$.

Beasley (W. G.), The Language Problem in the Anglo-Japanese Negotiations of 1854, 746-758.

BeEston (A. F. L.), Idrisi's Account of the British Isles, 265-280 ; A Sabaean Boundary Formula, 1-3.

Beginning Chinese (J. de Francis), 251-2.

Bek (Khalĩ́, MardaM), ed. Diwan Ibn 'Unayn, 231-2.

Bengali Literature (J. C. Ghosh), 510-511.

Benveniste (E.), Noms d'Agent et Noms d'Action en Indo-Européen, 792-5.

Bhāskari. A Commentary on the Iśvarapratyabhijñavimarśinī of Abhinavagupta (od. K. A. Subramania Iyer and K. C. Pandey), 1067. BrRch (C.), rev., 518-520.

Burge (J. Kingsley), A Guide to Turkish Area Study, 1062-3.

Blazons of the "Baptistère de Saint Louis", The (D. S. Rice), 367-380.

Buoch (J.), Canon Bouddhique Päli (Tipițaka), texte et traduction. Tome I, Fascicule I, 1050-1 ; Les Inscriptions d'Asoka, 1066.

BLoк (H. P.) ed. A Swahili Anthology with notes and glossaries, 529-531.

Boodberg (P. A.), UCJ : an Orthographic System of Notation and Transcription for Sino-Japanese, 520-3 .

Book of Beliefs and Opinions, The (S. Gaon), 504-5.

Book of Chao, The (W. Liebenthal), 1053-5.

Boxer (C. R.), Fidalgos in the Far East, 1550-1770: Fact and Fancy in the History of Macao, 1068.

Boyce (M.), Sadwẽs and Pēsūs, 908-915.

BoYle (J. A.), A Practical Dictionary of the Persian Language, 780-2.

bram, 128-9.

Brasses of Badr al-Din Lu'lu', The (D. S. Rice), 627-634

Brovar (J.), "Thus have I Heard ...," 416-426; rev., 244-7; 785-790; 1062 ; 1066-7.

Buddhistische Philosophie (C. Regamey), 1067.

Bukawa, a tonal language of New Guinea, $184 \mathrm{ff}$.

Burrow (T.), rev., 237-8.

\section{C}

Candana, 926-930.

Canon Bouddhique Päli (Tipitaka), texte et traduction. Tome I, Fascicule I (J. Bloch, J. Filliozat and L. Renou), 1050-1.

Cantonese Primer (Yuen Ren Chao), 725-745. Capell (A.), Two Tonal Languages of New Guinea, 184-199. 
Carnochan (J.), A Study of Quantity in Hausa, 1032-1044.

Caucasica in the History of Mayyāfāriqin (V. Minorsky), 27-35.

Caucasica II : 1. The Georgian maliks of Ahar (V. Minorsky), 868-877.

Chang Tsung-Ch'ien, Literary Chinese by the Inductive Method. Vol. I : The Hsiao Ching, 516-17.

Chao (YUen ReN), Cantonese Primer, 725-745.

Character and Structure of the Action in Maori (J. Prytz Johansen), 792.

*Charnglih, 460.

Chinese Language : An Essay on its Nature and History, The (B. Karlgren), 1060-2.

Chinn eny (J. D.), rev., 517-18.

Choksey (R. D.) ed. The Last Phase: Selections from the Deccan Commissioner's files (Peshwa Daftar), 1815-1818, 796-7.

Christian and Muslim Theology as Represented by Al-Shahrastānī and St. Thomas Aquinas (A. Guillaume), 551-580.

Clark (T. W.), rev., 510-11.

Clodd (H. P.), Malaya's First British Pioneer : the life of Francis Light, 795-6.

CaEd ks (G.), Les États Hindouisés d'Indochine et d'Indonésie, 511-16.

Coope (A. F.) rev., 248-9.

Count Todtleben's Expedition to Georgia, 1769-1771, according to a French eyewitness (D. M. Lang), 878-907.

Crent (H. G.), Literary Chinese by the Inductive Method. Vol. I : The Hsiao Ching, 516-17.

Cruelty as a Ground for Divorce at Burmese Buddhist Law (A. Gledhill), 433-442.

CRump, Jr, (J. I.), ed. Selections from the Shui-hv Chuan, 249.

\section{D}

Dahan (Sami), De l'éthique par al-wazir Abū1-Qāsim al-Magiribi (418/1027). I. Texte arabe, 778.

DĀrāB (G. H.), Persian Composition, 507-8.

Dasgupta (ShashibhusaN), Obscure Religious Cults as Background of Bengali Literature, 247-8.

Dasgupta (S. N.) ed. A History of Sanskrit Literature, Classical Period, 244-7.

DANIELS (F. J.), rev., 520-3.

David (M.), Les Dieux et le Destin en Babylonie, 783-5.

Davies (C. Coliris), rev., 1065.

Daytzong Shyrluh, 458-9.

De l'éthique par al-wazir Abū-l-Qāsim alMaǵribi (418/1027). I. Texte arabe (Sami Dahan), 778.

Demombynes (GaUdhrRoY), Ibn Qotaïba, Introduction au Livre de la Poésie et des Poètes, 232-4.

Desabhāsās, three fragments of, $410 \mathrm{ff}$.

Descriptive Catalogue of the Persian, Urdu, and Arabic Manuscripts in the Panjab University Library. Vol. I, fasc. $i$ (S. M. Abdullah), 508-9.

Dhammapada, The (S. Radhakrishnan), 1067. dharma, 656.

Dictionary of the Hausa Language (R. C. Abraham and Malam Mai Kano), 524-9.
Dieux et le Destin en Babylonie, Les (M. David, 783-5.

Digoron Word-List (E. J. A. Henderson and H. W. Bailey), 381-8.

Diwan Ibn 'Unayn (ed. Khalil Mardam Bek), 231-2.

DORE (R. P.), rev., 253-4.

Draxt-ì Asūríg, a Pahlavi poem, $641 \mathrm{ff}$,

Dubb, a Yemenite Djinn, 5-6.

Duchesne-Guillemin (J.). See Guillemin (J. Duchesne-).

Dumont (Paul-Emile), The Horse-Sacrifice in the Taittiriya-Brāhmaṇa, 785-7.

\section{$\mathbf{E}$}

Edicts of Asoka (G. Srinivasa Murti and A. N. Krishna Aiyangar), 1066.

Elenco dei Manoscritti Persiani della Biblioteca Vaticana (E. Rossi), 235-6.

Euiss fefr (N.), Thèmes et Motifs des Mille et une Nuits. Essai de Classificalion, 1063.

Epigrams attributed to Bhartrhari, The (ed. D. D. Kosambi), 787-789.

États Hindouisés d'Indochine et d'Indonésie, Les (G. Ccedès), 511-16.

Evaxs (E. M.), rev., 531-4.

\section{$\mathbf{F}$}

Al.Fakhrī (Muh. b. 'Alī b. TTabāțabā), 504.

False Jayhānī, A. (V. Minorsky), 89-96.

fazz, 136.

Fidalgos in the Far East, 1550-1770: Fact and Fancy in the History of Macao (C. R. Boxer), 1068.

Filsiozat (J.), Canon Bouddhique Pāli (Tipitaka), texte et traduction. Tome 1 , Fascicule I, 1050-1.

FirTH (J. R.) and ADAM (H. J. F.), Improved Techniques in Palatography and Kymo. graphy, 771-4.

Fleisch (H.), Introduction à l'étude des Langues Sémitiques, 779.

Fonkmst (R. A. D.), The Ju-Shêng tone in Pekingese, 443-7 ; rev., 1055-1060, 1068.

Francis (J. de) Beginning Chinese, 251-2.

Free Will and Predestination in Early Islam (W. Montgomery Watt), 775-6.

French in India: first establishment and struggle, The (S. P. Sen), 797.

From the Land of Sheba (ed. S. D. Goitein), 234-5.

Fürer-Haimendorf (C. von). See Haimendorf (C von Fürer-).

GAON (S.), The Book of Beliefs and Opinions, 504-5.

Gaudefroy-Demombynes. See Demombynes (Gaudefroy-).

gauśurya, $391 \mathrm{ff}$.

Geiger's Theory of "Vowel-Levelling ", criticism of, $166 \mathrm{ff}$.

ggośẗ̈, 931 . 
Ghirshman (R.), Inecriptions Pehlvi des Plats Sassanides du Musée de l'Ermitage, 916-19.

Grosh (J. C.), Bengali Literature, 510-11.

GibB (H. A. R.), Modern Trends in Islam, 229-230.

GIBRAN (K

GILES (L.), rev., 249-251, 797-800, 1060-2.

Gleanings from the Kuvalayamāla Kahā (A. Master), I, 410-15 ; II, 1004-1016.

Glederil (A.), Cruelty as a Ground for Divoree at Burmese Buddhist Law, 433-442.

GoITeIn (S. D.) ed. From the Land of Sheba, 234-5.

Goncalves (J.), Os Portugueses e o Mar das fndias, $240-4$.

Grammar of the Nepali Language, $A$ (W. R. J. Morland-Hughes), 240.

Gray (L. H.), The Narrative of Bhoja, 1067.

Guide to Turkish Area Study, A (J. Kingsley Birge), 1062-3.

Gurluaume (A.), Christian and Muslim Theology as Represented by Al-Shahrastāni and St. Thomas Aquinas, 551-580; Is Episcopacy a Jewish Institution ?, 23-6 ; rev., 229-234, 504-7, 775-9, 1063, 1065-6.

Guillemin (J. Duchesne-), Yasna 45 and the Iranian Calendar, 635-640.

\section{$\mathbf{H}$}

Hadramawt, new MSS. from, 281-307, 581601 ; list of libraries, 285-9.

Hadrami history, sources for, $283 \mathrm{f}$.

Ḥadrami scholars, subject-matter treatrd by, $282 \mathrm{f}$.

Hatmendorf (C. von Fürer-), rev., 790-1, 1046-8.

Hatmendorf (C. von Fürer and E.), The Aboriginal Tribes of Hyderabad. Vol. III : The Raj Gonds of Adilabad, a Peasant Culture of the Deccan. . Book I : Myth and Ritual, 1048-9.

HALL (D. G. E.), rev., 511-16, 1051-3.

Handbook of Diplomatic and Political Arabic, $A$ (B. Lewis), 234.

Hanifa (Abu), laws of, $357 \mathrm{ff}$.

Hansford (S. Howard), rev., 1068-9.

Harries (Lyndon), A Poem from Siu, 759770 ; rev., 529-531.

Harrison (J. B.), rev., 795-7.

Hayy b. Yaqzān (İbn Sinā), 845-7.

Henderson (E. J. A.), A Phonetic Study of Western Ossetic [Digoron], 36-79.

Henderson (E. J. A.) and Bailey (H. W.), Digoron Word-List, 381-8.

Hendriksen (H.), The Three Conjugations in Sinhalese 154-165.

Hennina (W. B.), The Aramaic Inscription of Asoka found in Lampāka, 80-88; A Pahlavi Poem, 642-8.

Herluoh Chuenchiou, 461.

Historical Grammar of Apabhramśa (G. V. Tagore), 509.

Historical Grammar of Inscriptional Prakrits (Madhukar Anant Mehendale), 239-240.

Historiens arabes (tr. J. Sauvaget), 229.
History of Sanskrit Literature, Classical Period, $A$ (ed. S. N. Dasgupta), 244-7.

IItA PE, The Origin and Development of the Burmese Composite Word 605onई: (Mô Kwan:), 427-432.

Homicide in Islamic Law : T. The Concept of the Offence: Tort or Crime? (J. N. D. Anderson), 811-828.

Horse-Sacrifice in the Taittiriya-Brāhmana, The (Paul-Émile Dumont), 785-7.

Hughes (W. R. J. Morland-), A Grammar of the Nepali Language, 240.

Humàyūn in Persia (Sukumar Ray), 1065.

Hussein (T.), The Stream of Days, 230-1.

HutTon (J. H.), rev., 1048-9.

Hyslop (K, R. Maxwel.L-), rev., 783-5.

I

Ibn 'Arabi (Muhyid-Dīn), 850-3.

Ibn Qotaiba, Introduction au Livre de la Poésie et des Poètes (ed. Gaudefroy-Demombynes), $232-4$.

Idrisi's Account of the British Isles (A. F. L. Beeston), 265-280.

Improved Techniques in Palatography and Kymography (J. R. Firth and H. J. F. Adam), 771-4.

Influence of Hermetic Literature on Moslem Thought, The (A. E. Affifi), 840-855.

Inscriptions d'Asoka, Les (J. Bloch), 1066.

Inscriptions Pehlvi des Plats Sassanides du Musée de l'Ermitage (R. Ghirshman), 916-19.

Introduction à l'étude des Langues Sémitigues (H. Fleisch), 779.

Introduction à l'histoire de l'Orient Musulman (J. Sauvaget), 228-9.

Invalid and Void Marriages in Hanafi Law (J. N. D. Anderson), 357-366.

Irano-Indica (H. W. Bailey), II, 121-139 ; III, 399-409 ; IV, 920-938.

Is Episcopacy a Jewish Institution? (A. Guillaume), $23-6$.

Islam in the Sudan (J. Spencer Trimingham), 779-780.

Iyfr (K. A. Sobramanta) and Pandey (K. C.) ed. Bhäskarí. A Commentary on the Íśvara pratyabhijñavimarşini of Abhinavagupta, 1067.

$$
\text { J }
$$

Jayhāni, false texts of, $89 \mathrm{ff}$.

Jewish Artists of the Nineteenth and Twentieth Centuries (K. Schwarz), 1064-5.

Jiannjong Shyrluh, 459.

Jihmen Jihluann, 461 .

*Jiow Tarngshu, $448 \mathrm{ff}$.

Johansen (J. PRY'T), Character and Structure of the Action in Maori, 792.

Journal of Jewish Studies, 227-8.

Ju-Shêng tone in Pekingese, The (R. A. D. Forrest), 443-7. 


\section{K}

Kan-ji, a new method comprising 2,700 SinicoJapanese characters (A. R. Nykl), 253-4.

Kano (Malam MaI) and Arraham (R. C.), Dictionary of the Hausa Language, 524-9.

(Kara-) Kirghiz Language, The (S. Wurn), 97-120.

KARLGREN (B.), The Chinese Language: An Essay on its Nature and History, 1060-2.

Kāš $\gamma a r i \overline{1}$, two words of, $404 \mathrm{f}$.

kavsa, $393 \mathrm{ff}$.

khara, 930.

Khotan, vocabulary of, $121 \mathrm{ff}$.

Kevlusi (S. A.), Ma'rūf ar-Rușãfī, 1875-1945, 616-626.

Kitāb Zajr al-nafs, 853-4.

Kosambi (D. D.), ed. The Epigrams attributed to Bhartrhari, 787-9.

Kremsmayer (Haymo), tr. Laotse, Tao Te King, 249-251.

Krorayina documents, Iranian words in, $121 \mathrm{ff}$.

Ktieb Gob, maqlub mill-Lhudi (tr. P. P. Saydon), 225-6.

luth'akṣira, kuth'ekșiza, $397 \mathrm{ff}$.

\section{T.}

LAMM (C. J.) and Zetrersteen (K. V.), Mohammed Asafi, The Story of Jamàl and Jalāl, 236-7.

Lamotre (E.), tr. Le Traité de la Grande Vertu de Sagesse, 789-790.

Land of Enchanters (ed. B. Lewis), 507.

Lana (D. M.), Count Todtleben's Expedition to Georgia, 1769-1771, according to a French eyewitness, 878-907.

Language Problem in the Anglo-Japanese Negotiations of 1854, The (W. G. Beasley), $746-758$.

Laotse, Tao Te King (tr. Haymo Kremsmayer), 249-251.

Last Phase: Selections from the Deccan Commissioner's files (Peshwa Daftar), 1815-1818, The (ed. R. D. Choksey), 796-7.

Lewis (B.), An Apocalyptic Vision of Islamic History, 308-338; A Handbook of Diplomatic and Political Arabic, 234 ; Land of Enchanters, 507 ; rev., 226-9.

LEwis (M. B.), Teach Yourself Malay, 248-9.

Liebenthal (W.), The Book of Chao, 1053-5.

Literary Chinese by the Inductive Method. Vol. I: The Hsiao Ching (ed. H. G. Creel, Chang 'Tsung-Ch'ien and R. C. Rudolph), 516-17.

Locke (M. A.), rev., 516-17.

\section{$\mathbf{M}$}

Malaya's First British Pioneer: the life of Francis Light (H. P. Clodd), 795-6.

Malay History from Chinese Sources (R. O. Winstedt), 182-3.

Malays: A Cultural History, The (Sir R. Winstedt), 1051-3.

*mamati, 131-2.

manare, 130-31.

Mandarin Primer-with Character Text (Yuen Ren Chao), 517-18. mara-, 134-5.

Ma'rūf ar-Ruşāfī, 1875-1945 (S. A. Khulusi), 616-626.

Master (A.), Gleanings from the Kuvalayamālā Kahā I, 410-415 ; II, 1004-1016 ; rev, 238-240, 509 .

Materials for South Arabian History (R. B. Serjeant), I, 281-307; II, 581-601.

Maxwell-Hyslop (K. R.). See Hyslop (K. R. Maxwell-).

Mayyäfäriqin, Caucasica in the History of, 27-35.

Mehendate (Madhukar Anant), Historical Grammar of Inscriptional Prakrits, 239-240.

Melilah, a volume of studies (ed. E. Robertson and M. Wallenstein), 226-7.

Miniature in an Autograph of Shihāb al-din

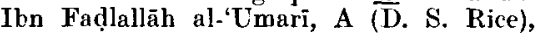
856-867.

Minorsky (V.), Caucasica in the History of Mayyāfāriqīn, 27-35; Caucasica II : 1. The Georgian naliks of Ahar, 868-877 ; A False Jayhānī, 89-96.

Mîrzà Mug̣ammad Khān Qazvĩni, obituary of, 547-550.

Modern Trends in Islam (H. A. R. Gibb), 229-230.

Mohammed Asafi, The Story of Jamãl and Jalàl (K. V. Zetterstéen and C. J. Lamm), $236-7$.

Mo Kuan in Burmese, 428-9.

M6 Kwan: in Burmese, 429-432.

Morland-Hughes (W. R. J.). See Hughes (W. R. J. Morland).

Motoori-Norinaga's Contribution to a Scheme of Japanese Grammar (S. Yanada), 474-503.

müla-mantra of the Praña päàme, the, 934-7.

MÜNSTER BERg (H.), A Short History of Chinese Art, 1068-9.

Murti (G. Srinivasa) and Aiyangar (A. N. Krisina), Edicts of Aśoka, 1066.

\section{$\mathrm{N}$}

NADEL (S. M.), The Nuba : an anthropological study of the hill tribes in Kordofan, 523-4.

NĀGĀRJUNA, Le Traité de la Grande Vertu de Sagesse, 789-790.

Nam, an Ancient Language of the Sino-Tibetan Borderland (F. W. Thomas), 1055-1060.

Nàma-yi Aristūtālis dar Bāra-yi Hunar-i Shi'r (Suhail Afnān), 782-3.

Narrative of Bhoja, The (I. H. Gray), 1067.

na/ta nominal plus high-tone in Hausa, $1039 \mathrm{ff}$.

$n e / c e$ in Hausa, $1033 \mathrm{ff}$

New materials on the Tabaqāt al-shu'arì of al-Jumahi (A. J. Arberry), I, 7-22 ; II, $602-615$.

Ni Ale Ojo Kan (J. S. Ogunlesi), 1069.

Noms d'Agent et Noms d'Action en IndoEuropéen (E. Benveniste), 792-6.

Notes on Ptolemy (J. Ph. Vogel), 146-153.

Nuba: an anthropological study of the hill tribes in Kordofan, The (S. M. Nadel), 523-4.

NYKL (A. R.), Kan-ji, a new method comprising 2,700 Binico-Japanese characters, 253-4; ed. Selections from Hispano-Arabic Poetry, 505-7. 
o

Obscure Religious Cults as Background of Bengali Literature (Shashibhusan Dasgupta), 247-8.

Oqunlesi (J. S.), Ni Ale Ojo Kan, 1069.

Origin and Development of the Burmese Composite Word 60โmฐ: (Mo Kwan॰), The (Hla Pe), 427-432.

Os Portugueses e o Mar das Indias (J. Gonçalves), $240-4$.

$\mathbf{P}$

Pahlavi Poem, A (W. B. Henning), 642-8. pamjsi-vasări, 930-1.

Pandey (K. C.) and Iyer (K. A. SubraMANIA), ed. Bhäskari. A Commentary on the İsvarapratyabhijñavimarsinin of Abhina. vagupta, 1067.

Paradigms and Exercises in Syriac Grammar (T. H. Robinson), 1064 .

Parry (V. J.), rev., 1062-3.

Parsons (F. W.), rev., 524-9.

Patkar (Madhukar Mangesh) ed. AnekārthaTilaka of Mahipa, 237-8.

Persian Composition (G. H. Dārāb), 507-8.

Phonemics : a technique for reducing languages to writing (K. L. Pike), 531-4.

Phonetic Study of Western Ossetic (Digoron), A (E. J. A. Henderson), 36-79.

Phonology of the Sinhalese Inscriptions up to the End of the Tenth Century (P. B. F. Wijeratne), 166-181.

PIKE (K. I.), Phonemics: a technique for reducing languages to writing, 531-4.

plāvī, 937-8.

Poem from Siu, A (Lyndon Harries), 759-770.

Popular Shī'ism (A. S. Tritton), 829-839.

Practical Dictionary of the Persian Language, $A$ (J. A. Bovle), 780-2.

prūvã., 920-6.

Pulleyblank (E. G.), The Tzyjyh Tongjiann Kaoyih and the Sources for the History of the Period 730-763, 448-473.

Purity, references to in the Tumshuq Karmavàcanä, 656-8.

$\mathbf{R}$

Radia Krishnan (S.), The Dhammapada, 1067.

Ray (Sukumar), Humāyūn in Persia, 1065.

Reasons for Laws, The (Ibn Babuye), $829 \mathrm{ff}$.

Recent Work on the Indus Civilization (A. L. Basham), 140-5.

Reforms and Religious Ideas of Sir Sayyid Ahmad Khān, The (J. M. S. Baljon, Jr.), $1065-6$.

REgaMEY (C.), Buddhistische Philosophie, 1067.

Renou (L.), Canon Bouddhique Päli (Tipitaka), texte et traduction. Tome I, Fascicule I, 1050-1.

RicF (D. S.), The Blazons of the " Baptistère de Saint Iouis ", 367-380; The Brasses of Badr al-Din Lu'lu', 627-634; A Miniature in an Autograph of Shihàb al-din Ibn Fadlallāh al.'Umarī, 856-867.
RICHARDS (A. I.) ; rev., 523-4.

risaya-, $405 \mathrm{f}$.

ROBERTSON (E.) and Wallenstein (M.), Melilah, a volume of sludies, 226-7.

Robinson (T. H.), Paradigms and Exercises in Syriac Grammar, 1064.

Rossi (E.), Elenco dei Mansscritti Persiani della Biblioteca Vaticana, 235-6.

RowLANDS (E. C.); rev., 1069.

RUDoLPH (R. C.), Literary Chinese by the Inductive Method. Vol. I : The Hsiao Ching, $516-17$.

s

Sabaean Boundary Formula, A (A. F. L. Beeston), 1-3.

Sadwēs and Pēsūs (M. Boyce), 908-915.

ȘALĀH AL-Dín AL-MUNAJJID, Wulātu Dimashq fi 'l-'ahdi 'l-'uthmänì wah̄u yatadammanu "al-Bāshāt wal-Qudāt" li (Muhammad) ibn Jum'a (al-Maqqār) “Wa'l-Wuzarā'ulladhina hakamū Dimashq" li (Raslän) ibn Yahyya al-Qārī wamașädira 'an ta'rìkh Dimashq ayyāma 'l.'uthmäniyīn, 777.

śāra-, $389 \mathrm{ff}$.

SaUvaget (J.), tr. Historiens arabes, 229 ; Introduction à l'histoire de l'Orient Musulman, 228-9.

SAYDON (P. P.) tr. Ktieb Gob, maqlub millLhudi, 225-6.

Schinduer (B.), ed. Asia Major, Vol. I, part i, $799-800$.

Schmidt (P. Wilhelm), Der Ursprung der Gottesidee: eine historisch-kritische und positive Studie, III Teil, 1046-8.

Schwarz (K.), Jewish Artists of the Nineteenth and Twentieth Centuries, 1064-5.

Scotr (N. C.), rev., 792.

Shadi (J. B.), rev., 1064-5.

Selections from Hispano-Arabic Poetry (ed. A. R. Nykl), 505-7.

Selections from the Shui-hu Chuan (ed. J. I. Crump, Jr.), 249.

Sen (S. P.), The French in India : first establishment and struggle, 797.

Serjeant (R. B.) Materials for South Arabian History I, 281-307; II, 581-601 ; Two Yemenite Djinn, 4-6 ; rev., $779-780$.

Shafer (R.), Studies in the Morphology of Bodic Verbs I, 702-724 ; II, 1017-1031.

Al-Shahrastani, theology of, $551 \mathrm{ff}$.

*Shin Tarngshu, 457.

Short History of Chinese Art, A (H. Münsterberg), 1068-9.

Shyuantzong Shinq Shuu Jih, 461-2.

Shyuantzong Shyrluh, 457-8.

śiksāpada, $660 \mathrm{ff}$.

simje in Khotanese, 933.

Simon (W.), rev., 251-2.

Sīñ (IBN), Hayy b. Yaqzān, 845-7.

SNelugrove (D. L.), rev., 1053-5.

Some Prosodic Aspects of Retroflexion and Aspiration in Sanskrit (W. S. Allen), 939946.

sor, $136 \mathrm{ff}$

Sotho-Nguni Orthography and Tone-Marking (A. N. Tucker), 200-224, 
Speak Chinese (M. Gardner Tewksbury), 518520.

Stede (D. A. L.), rev., 1050-1.

STEWART (J. A.), obituary of, 259-264.

Stone Age Cullures of Bellary (B. Subbarao), 790-1.

Stream of Days, The (T. Hussein), 230-1.

Studies in the Morphology of Bodic Verbs (R. Shafer), I, 702-724; II, 1017-1031.

Study of Quantity in Hausa, A (J. Carnochan), 1032-1044.

Subbarao (B.), Stone Age Cultures of Bellary, 790-1.

Suhtzong Shyrluh, 458.

Summers (G. M.), rev., 247-8.

sūr, $136 \mathrm{ff}$.

Swahili Anthology with notes and glossaries, $A$ (ed. H. P. Blok), 529-531.

\section{$\mathbf{T}$}

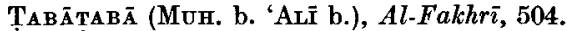
TAGore (G. V.), Historical Grammar of Apabhramśa, 509 .

Tà'iyyatu 'ámiri bni 'àmiri 'l-Basri (ed. Shayk 'Abdu-'I Qādir 'l-Maghribī), 776-777.

Tar-mi-ta, 400 ff.

Tarnglih, 459-460.

Teachers of Shihāb al-Dīn 'Umar al-Suhrawardi, The (A. J. Arberry), 339-356.

Teach Yourself Malay (M. B. Lewis), 248-9.

Tears and Laughter (Kahlil Gibran), 778.

Tewhsbury (M. Gardner), Speak Chinese, 518-520.

Thèmes et Motifs des Mille et une Nuits. Essai de Classification (N. Elisséeff), 1063.

Thomas (F. W.), Nam, an Ancient Language of the Sino-Tibetan Borderland, 1055-1060.

Three Conjugations in Sinhalese, The (H. Hendriksen), 154- 65.

"Thus Have I Heard..." (J. Brough), $416-426$.

Traité de la Grande Vertu de Sagesse, Le (tr. E. Lamotte), 789-790.

Transcription of Cantonese, A (K. M. A. Barnett), 725-745.

Triminaha (J. Sphnoer), Islam in the Sudan, $779-780$.

Triśarana, 652-4.

Tritton (A. S.), Popular Shīism, 829-839; rev., 234-5, 504.

Tucker (A. N.), Sotho-Nguni Orthography and Tone-Marking, 200-224.

Tumshuq Karmavāicanā, The (H. W. Bailey), 649-670.

tuxärìk, 403 f.

Two Tonal Languages of New Guinea (A. Capell), 184-199.

Two Yemenite Djinn (R. B. Serjeant), 4-6.

Tzyjyh Tongjiann Kaoyih and the Sources for the History of the Period 730-763, The (E. G. Pulleyblank), 448-473.

\section{$\mathrm{U}$}

UCJ : an Orthographic System of Notation and Transcription for Sino-Japanese (P. A. Boodberg), 520-3.
' $U d h r \bar{u} t$, a Yemenite Djinn, 4-5.

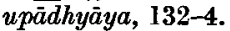

Vrsprung der Gottesidee : eine historischkritische und positive Studie, III Teil, Der (P. Wilhelm Schmidt), 1046-8.

\section{V}

Vale (Ramchandra Nakayan), Verbal Composition in Indo-Aryan, 238-9.

Varnārhavarna Stotra of Mātrceta, The (D. R. Shackleton Bailey), I, 671-701 ; II, 9471003.

Verbal Composition in Indo-Aryan (Ramchandra Narayan Vale), 238-9.

Vogkt (J. Ph.), Notes on Ptolemy, 146-153.

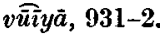

\section{W}

Wallenstein (M.) and Robertson (E.), Melilah, a volume of studies. 226-7.

WARD (I. C.), obituary of, 542-7.

Watr (W. Mon'sgomery), Free Will and Predestination in Early Islam, 775-6.

Wickens (G. M.), rev., 507-9, 780-2.

WiJfratne (P. B. F.), Phonology of the Sinhalese Inscriptions up to the End of the Tenth Century, 166-181.

WILkINSON (J. V. S.), rev., 236-7.

Winstedt (SIr RichaRd), Malay History from Chinese Sources, 182-3; The Malays: A Cultural History, 1051-3.

Wisdom of China, The (ed. Lin Yutang), $797-9$.

WitTek (P.), $A d$ BSOAS., xiii, 1950, p. 275 : grkh frt $=$ Oxford, 1045 .

Wulātu Dimashq fi 'l-'ahdi 'l-'uthmāni wahū vatadammanu "al-Bāshāt wal-Qudāt" li (Muhammad) ibn Jum'a (al-Maqqār) "Wa'lWuzarā'u-lladhīna hakamū Dimashq" li (Raslān) ibn Yahyya al-Qārì wamasāadira 'an ta'rīkh Dimashq ayyāma 'll'uthmäniyīn (Salāh al-Dīn al-Munajjid), 777.

Wurm (S.), The (Kara-) Kirghiz Language, 97-120.

\section{$\mathbf{Y}$}

Yabẹm, a tonal language of New Guinea, $184 \mathrm{ff}$.

Yanada (S.), Motoori-Norinaga's Contribution to a Scheme of Japanese Grammar, 474503.

Yasna 45 and the Iranian Calendar (J. Duchesne-Guillemin), 635-640.

Yöhay (RabBi Simon Ben), prayer of, $309 \mathrm{ff}$.

YUEN REN CHAO (Mandarin Primer-with Character Text), 517-18.

YUTANG (LIN), ed. The Wisdom of China, 797-9.

\section{Z}

ZetTersteen (K. V.) and Lamm (C. J.), Mohammed Asafī, The Story of Jamàl and Jalăl, 236-7. 